\title{
Cervical cancer epidemiology among HIV-infected women in North America
}

\author{
Gypsyamber D'Souza ${ }^{1 *}$, Yuezhou Jing ${ }^{1}$, Howard Strickler ${ }^{10}$, Michael Silverberg ${ }^{2}$, Eric Engels ${ }^{3}$, Ronald Bosch ${ }^{4}$ \\ John T Brooks ${ }^{5}$, Robert Dubrow ${ }^{6}$, Joseph Eron${ }^{7}$, Kelly Gebo ${ }^{8}$, M J Gill ${ }^{9}$, Bob Hogg ${ }^{11}$, Mari Kitahata ${ }^{12}$, Marina Klein ${ }^{13}$, \\ Richard Moore ${ }^{8}$, Sean Rourke ${ }^{14}$, Alison G Abraham
}

From $12^{\text {th }}$ International Conference on Malignancies in AIDS and Other Acquired Immunodeficiencies (ICMAOI)

Bethesda, MD, USA. 26-27 April, 2010

\section{Background}

Initial studies suggest immunosuppression may be associated with the increased rates of precancerous cervical lesions observed in HIV-infected compared with HIVuninfected individuals, but few studies have large enough populations to study the effect on invasive cancer. To characterize the incidence of cervical cancer among HIV-infected women in the HAART era, we examined data from the NA-ACCORD HIV cohort collaboration of IeDEA.

\section{Materials and methods}

This analysis includes data from 13 North American cohorts of HIV-infected women that collected clinically confirmed or cancer registry-linked data on invasive cervical cancer. Cervical cancer-free women were followed from the first HAART era CD4+ measurement (1996 onwards) until the earliest of: cervical cancer diagnosis, lost to followup, death, or December 2007. Incidence rate overall, by calendar period, and by first CD4+ cell count after 1995 (baseline) were standardized for age using the 2000 U.S. standard population.

\section{Results}

Among the 16,467 HIV-infected women free of disease at baseline, 102 cases of invasive cervical cancer were reported, yielding an age-standardized incidence rate of 114 per 100,000 person-years (95\% CI: $88-139$ ). Of those cases, 40 (39\%) were HAART-naive at the time of diagnosis. Among women $\leq 39,40-49$, and $\geq 50$ years of

\footnotetext{
*Correspondence: gdsouza@jhsph.edu

'Department of Epidemiology, Johns Hopkins Bloomberg School of Public Health, Baltimore, MD, USA

Full list of author information is available at the end of the article
}

age the incidence rates were 122,142 , and 89 per 100,000 person-years, respectively. The age-standardized incidence rates by calendar periods for 1996-1999, 20002003, and 2004-2007 were 133, 152, and 87 per 100,000 person-years, respectively, showing no trend. The agestandardized incidence rates by baseline CD4+ categories of $>350,200-350$ and $<200$ cells $/ \mu \mathrm{L}$ were 68,113 , and 185, respectively, indicating an increasing rate with declining CD4+ cell count $\left(\mathrm{P}_{\text {trend }}<0.001\right)$. Among 13,716 HIV-negative women free of disease in these cohorts, there were 10 invasive cervical cancers for an incidence of 12.3 per 100,000 person-years (95\% CI 6.6-23), similar to the age-adjusted SEER population incidence of 8.2 per 100,000 person-years.

\section{Conclusions}

In this large collaboration of North American HIV cohorts, the estimate of cervical cancer incidence was almost 10-fold higher among HIV-infected than uninfected women in these cohorts. Although an effect of increased sexual risk-taking in HIV-infected women and/or differences in screening cannot be excluded, the strong association with lower baseline CD4+ cell count suggests a single low CD4 measurement may predict increased cervical cancer risk. It is unclear whether improvements in HIV-therapies during the HAART era have influenced cervical cancer rates; although no significant trend in incidence was observed over time, a decrease was observed in 2004-07.

\section{Acknowledgements}

This work is presented on behalf of the North American AIDS Cohort Collaboration on Research and Design (NA-ACCORD) of leDEA. 
This article has been published as part of Infectious Agents and Cancer Volume 5 Supplement 1, 2010: Proceedings of the $12^{\text {th }}$ International Conference on Malignancies in AIDS and Other Acquired Immunodeficiencies (ICMAOI). The full contents of the supplement are available online at http://www.biomedcentral.com/1750-9378/5?issue=S1.

\section{Author details}

'Department of Epidemiology, Johns Hopkins Bloomberg School of Public Health, Baltimore, MD, USA. ${ }^{2}$ Kaiser Permanente Northern California, Oakland, CA, USA. ${ }^{3}$ Division of Cancer Epidemiology and Genetics, NCl, NIH, Bethesda, MD, USA. ${ }^{4}$ Department of Biostatistics, Harvard University, Boston, MA, USA. ${ }^{5}$ Centers for Disease Control and Prevention, Atlanta, GA, USA. ${ }^{6}$ Division of Chronic Disease Epidemiology Yale University, New Haven, CT, USA. ${ }^{7}$ Division of Infectious Diseases, School of Medicine, University of North Carolina, Chapel Hill, NC, USA. ${ }^{8}$ Department of Medicine, Johns Hopkins School of Medicine, Baltimore, MD, USA. ${ }^{9}$ Department of Medicine, University of Calgary, Calgary, Canada. ${ }^{10}$ Department of Epidemiology, University of California at San Francisco, San Francisco, CA, USA. ${ }^{11}$ BC Centre for Excellence in HIV/AIDS, Vancouver, Canada. ${ }^{12}$ Department of Medicine, University of Washington, Seattle, WA, USA. ${ }^{13}$ McGill University, Montreal, Canada. ${ }^{14}$ Department of Psychiatry, University of Toronto, Toronto, Canada.

Published: 11 October 2010

doi:10.1186/1750-9378-5-S1-A9

Cite this article as: D'Souza et al: Cervical cancer epidemiology among HIV-infected women in North America. Infectious Agents and Cancer 2010 5(Suppl 1):A9.

\section{Submit your next manuscript to BioMed Central and take full advantage of:}

- Convenient online submission

- Thorough peer review

- No space constraints or color figure charges

- Immediate publication on acceptance

- Inclusion in PubMed, CAS, Scopus and Google Scholar

- Research which is freely available for redistribution

Submit your manuscript at www.biomedcentral.com/submit 